\title{
ANALISIS KEINTEGRASIAN MUATAN PELAJARAN SEKOLAH DASAR KELAS III TEMA PERKEMBANGAN TEKNOLOGI DALAM IMPLEMENTASI KURIKULUM 2013
}

\author{
Hairullah $^{1}$, N. Dantes ${ }^{2}$, A.A.I.N. Marhaeni ${ }^{3}$ \\ ${ }^{123}$ Program Studi Pendidikan Dasar \\ Universitas Pendidikan Ganesha \\ Singaraja, Indonesia \\ e-mail: hairullahpsm@gmail.com ${ }^{1}, \underline{\text { dantes@undiksha.ac.id }}{ }^{2}$, \\ ngr.marhaeni@undiksha.ac.id ${ }^{3}$
}

\begin{abstract}
Abstrak
Peneletian yang dilakukan adalah penelitian analisis dokumen (Documentary Analysis). Dokumen yang di maksud adalah buku guru dan buku siswa tema perkembangan teknologi.Penelitian ini bertujuan untuk mengetahui dan mendeskripsikan keintegrasian pada materi pembelajaran, rancangan langkah-langkah kegiatan pembelajaran, rancangan penilaian, rancangan media dan sumber belajar Sekolah Dasar Kelas III tema Perkembangan Teknologi Penelitian ini menggunakan deskriptif kualitatif. Teknik pengumpulan data yang digunakan adalah metode dokumentasi. Analisis data yang digunakan yaitu pengumpulan data, reduksi data, penyajian data, dan penarikan kesimpulan. Berdasarkan analisis data, diperoleh hasil penelitian bahwa: 1) Terdapat keintegrasian pada materi pembelajaran dengan tingkat keintegrasian $98,7 \%$ kategori sangat baik dengan klasifikasi multidisipliner. 2) Terdapat keintegrasian pada rancangan langkah-langkah kegiatan pembelajaran dengan tingkat keintegrasian $79,3 \%$ kategori sedang dengan klasifikasi intradisipliner. 3) Terdapat keintegrasian pada rancangan penilaian dengan tingkat keintegrasian $71 \%$ kategori sedang dengan klasifikasi intradisipliner. 4) Terdapat keintegrasian pada rancangan media dan sumber belajar dengan tingkat keintegrasian 91\% kategori sangat baik dengan klasifikasi intradisipliner.
\end{abstract}

Kata Kunci: Keintegrasian; Kurikulum 2013; Muatan Pelajaran

\begin{abstract}
The research conducted was documentary analysis research (Documentary Analysis). The intended document is the teacher's book and the student's book on the theme of technological development. This research aims to identify and describe the integration in learning material, the design of the steps of learning activities, assessment design, media design and learning resources using descriptive qualitative. The data collection technique used is the documentation method. Analysis of the data used is data collection, data reduction, data presentation, and drawing conclusions. Based on data analysis, the results of the study are as follows: 1) There is integration in learning material with an integration level of $98.7 \%$, a very good category with multidisciplinary classification. 2) There is integration in the design of the steps of learning activities with an integration level of $79.3 \%$ in the medium category with intradisciplinary classification. 3) there is integration in the assessment design with an integration level of $71 \%$ of the moderate category with an intradisciplinary classification. 4) there is integration in the design of media and learning resources with an integration level of $91 \%$ the category is very good with intradisciplinary classification.
\end{abstract}

Keywords: Integration, Lesson Content, 2013 Curriculum

\section{PENDAHULUAN}

Upaya merevitalisasi mutu pendidikan merupakan bagian dari kepedulian semua stake holders terhadap pendidikan. Pendidikan merupakan salah satu yang menjadi keharusan bagi manusia dalam merawat dan memupuk intelektualnya supaya menjadi manusia yang memiliki kebermanfaatan untuk sesama. Berangkat dari itu pendidikan harus diperhatikan oleh semua lapisan stake holders. Terutama pada pendidikan 
formal yang mana siswa perlu diberikan bimbingam, pengajaran, pelatihan dan pendampingan. Hal ini sejalan untuk mengingat isi pembukaan UUD 1945 alenia IV yang menegaskan bahwa salah satu tujuan nasional bangsa Indonesia adalah "mencerdaskan kehidupan bangsa". Salah satu cara untuk mencerdaskan kehidupan bangsa adalah dengan meningkatkan mutu pendidikan.

Pendidikan pada Abad 21 ini beriringan dengan revolusi industri 4.0 menjadi tantangan tersendiri bagi bangsa Indonesia dalam menyesuaikan sistemnya dengan perkembangan jaman yang pesat ini. Bukan rahasia umum bahwasanya implikasi dari industry 4.0 berdampak pada aspek pendidikan, khususnya pendidikan di Sekolah Dasar. Sekolah Dasar adalah awal dari penanaman konsep ilmu pengetahuan, sehingga sangat mempengaruhi perkembangan siswa pada tahap selanjutnya. Untuk itu seorang harus memahami karakteristik peserta didik dan bahan pembelajaran yang akan diajarkan sesuai dengan perkembangan anak (developmentally approveriate practice) (Dantes, 2017:29). Disamping menyesuaikan dengan perkembangan anak, pendidik perlu menyesuaikan dengan perkembangan sains dan teknologi (Tirtarahardja \& Sulo, 2005:1) Dalam hal ini guru harus memposisikan dirinya sebagai fasilitator. Sebagaimana menurut Sani (2014: 63), peran guru dalam kegiatan mengumpulkan informasi adalah memfasilitasi atau membantu siswa menggunakan bahan dan peralatan.

$$
\text { Sekarang ini Indonesia }
$$

menggunakan kurikulum 2013 telah memasuki usia yang ke-7 tahun. Dinamika perjalanan kurikulum 2013 dalam pelaksanaannya mengalami banyak evaluasi dan penyempurnaan di berbagai hal baik pengelolaan/kebijakan, substansi, maupun metodologinya. Setelah melalui evaluasi kurikulum 2013 kembali dilaksanakan lagi sampai sekarang ini. Penerapan K13 sebagai upaya untuk memperbaiki kurikum yang sebelumnya. Dengan diterapkannya Kurikulum 2013 diharapkan dapat mengahasilkan peserta didik yang kompeten, unggul pada aspek kognitif, anggun dalam bersikap dan cakap dalam keterampilan. Dengan implementasi kurikulum 2013 ini diharapkan mampu menciptakan lulusan yang berkompeten, terutama pada pendidikan dasar. Karena pendidikan dasar merupakan pondasi dari pendidikan selanjutnya. Analogi yang sederhana jika sebuah bangunan dengan bangunan dasarnya tidak kuat maka bangunan tersebut tidak akan bertahan lama alias cepat roboh.

Di Sekolah Dasar Pembelajaran yang diterapkan dalam kurikulum 2013 adalah tematik terpadu (tematik integratif). Pembelajaran tematik integrative adalah pembelajaran yang mengintegrasikan berbagai Kompetensi Dasar dari macammacam mata pelajaran ke dalam suatu tema. Narti, dkk (2016) "Thematic learning is defined as a learning that is designed based on a particular theme" bahwa pembelajaran tematik didefinisikan sebagai pembelajaran dirancang berdasarkan tema tertentu. Pembelajaran dengan menintegrasikan seperti ini peserta didik tidak belajar konsep dasar secara parsial tetapi secara holistic (menyeluruh). Menurut salinan lampiran Permendikbud No. 67 tentang kurikulum sekolah dasar (2013: 132) pembelajaran tematik integratif merupakan pendekatan pembelajaran dengan mengintegrasikan berbagai kompetensi dari berbagai mata pelajaran ke dalam berbagai tema.

Senada dengan pendapat Randel (2010:85) mengatakan "integrated thematic instruction-based curricula stresses the integration of all disciplines to present students with learning experiences that are based on real-world application and structured to encourage higher-order learning". Yang berarti bawasanya pembejaran tematik integrative menekankan pada pengintegrasian semua disiplin ilmu dengan pengalaman belajar yang berbasis pengalaman siswa dan struktur dunia nyata, sehingga mendorong pembelajaran menjadi lebih bermakna.

Salah satu ruh dari kurikulum 2013 adalah pembelajaran tematik terpadu (Integrated thematic instruction) yang digunakan sebagai salah satu model pembelajaran yang efektif, karena dianggap mampu mewadahi atau mengakomodasi secara terpadu 
psikologis anak, fisik maupun akademik siswa. di dalam kelas atau di lingkungan lembaga pendidikan (Kemendikbud,2014: 15). Sebagaimana menurut La Iru dan Arihi dalam (Prastowo, 2013:119) mengatakan pembelajaran tematik dapat mmbangun kompetensi siswa yaitu dengan cara keterlibatan langsung siswa dalam pembelajaran dan konsep pembelajaran sambil melakukan (learning by doing). Menurut Nurul (2015:35) pembelajaran tematik integrative adalah suatu pendekatan pembelajaran mengintegrasikan berbagai macam kompetensi dasar beberapa mata pelajaran ke dalam tema. Jadi, pembelajaran tematik terapadu merupakan konsep pembelajaran yang mengaitkan beberapa mata pelajaran untuk memberikan pengalaman yang bermakna pada anak dan melihat pembelajaran sesuatu yang utuh tidak terpisah-pisah (holistic).

Model pembelajaran terpadu dari Forgaty yang diterapkan pada pembelajaran tematik terpadu adalah the webbed model (model jaring laba-laba) dan the integrated model sejalan dengan pembelajaran tematik terpadu di kurikulum jenjang SD di Indonesia. Pembelajaran tematik integratif terpadu tipe webbed adalah pembelajaran yang memposisikan tema sebagai acuan pelajaran.. Artinya, tema menjadi sentral dalam proses pembelajaran dengan model pembelajaran terpadu tipe webbed ini yang bisa memiliki keterkaitanantara satu dengan yang lainnya. Dalam satu tema dibuat bagaimana berbagai disiplin ilmu bisa dimasukan ke dalam tema tersebut agar bisa menghubungkan berbagai materi dan materi yang terikat oleh tema disusun secara berkesinambungan. Bahkan, menurut Julianto (2010: 56) "tipe webbed ini merupakan tipe pemaduan yang paling popular". Pemaduan dalam tipe ini dilakukan dengan menggunakan pembelajaran yang berpendekatan tematik integratif. Tema dapat mengikat kegiatankegiatan pembelajaran, baik dalam mata pelajaran tertentu maupun antar mata pelajaran.

Penerapan model pembelajaran tematik terpadu sebenarnya bukan hal baru di Indonesia, terutama di pendidikan dasar. Pada kurikulum KTSP 2006 mengamanatkan

bahwasanya pembelajaran di kelas rendah dalam hal ini kelas 1, 2, dan 3 menggunakan pendekatan tematik. Yang kemudian disempurnakan pelaksanaanya dalam kurikulum 2013 ini

Pelaksanaan kurikulum 2013 pemerintah mengeluarkan teks tematik berupa buku siswa dan buku guru sebagai pedoman proses pembelajaran. Jika dilihat dari prosedur pelaksanaan pembelajaran menggunakan kurikulum 2013, guru semestinya menentukan tema kemudian melakukan pemetaan KD dalam setiap sub tema. Tetapi dengan difasilitasi buku pegangan guru maupun buku siswa, guru tinggal melaksanakan pembelajaran dan penilaian. Rubrik penilaian juga sudah tersedia dalam buku guru. Keberadaan buku siswa disini bukan seperti kitab suci, artinya bahwa guru perlu menyesuaikan dan menganalisa apakah pada pembelajaran itu secara keutuhan materi sudah cukup atau belum, begitu juga dalam persepektif pembelajaran tematik terpadu, semua muatan dalam pembelajaran itu harus saling berkaitan yang diikat oleh tema. Ada beberapa aspek yang perlu diperhatikan dalam melihat keintegrasian pembelajaran tematik terpadu yaitu pada aspek materi, kegiatan pembelajaran, media/sumber belajar, dan penilaian. Buku teks tematik buku guru dan buku siswa adalah menjadi objek kajian dengan 4 aspek. Mengingat pentingnya buku teks tematik dalam rangka menyuksekan pelaksanaan kurikulum 2013, untuk itu perlu kiranya menganalisa sejauh mana keintegrasian yang terdapat dalam buku teks tematik yang dikeluarkan atau diterbitkan oleh Kemendikbud.

\section{METODE}

Pendekatan yang digunakan dalam penelitian ini adalah pendekatan kualitatif dengan deskriptif yaitu cara atau prosedur pemecahan masalah penelitian dengan cara memaparkan hasil analisis dokumen. Peneletian yang dilakukan adalah penelitian analisis dokumen (Documentary Analysis). Penelitian yang dilakukan terhadap informasi yang didokumentasikan dalam rekaman, baik 
gambar, suara, tulisan, atau lain-lain bentuk rekaman bisa dikenal dengan penelitian analisis dokumen atau Content analysis (Arikunto, 2013:244). Dokumen yang dianalisis adalah buku teks tematik terpadu Kurikulum 2013 Kelas III tema Perkembangan Teknologi yang disusun dan diterbitkan oleh Kemendikbud tahun 2018 yang terdiri dari buku guru dan buku siswa. Informan utama dalam penelitian yang dijadikan subyek penelitian ini adalah buku guru dan buku siswa kelas III tema Perkembangan Teknologi dalam Kurikulum 2013. Sedangkan objek dalam penelitian ini adalah Kurikulum 2013 yang ditinjau dari buku guru dan buku siswa kelas 3 tema Perkembangan Teknologi.

Pada penelitian ini mengumpulkan data dengan teknik studi dokumen. Dokumen yang dimaksud dalam penelitian ini adalah buku guru dan buku pegangan siswa tema Perkembangan Teknologi pada kurikulum 2013. Sedangkan Instrumen penelitian adalah alat yang digunakan untuk mengumpulkan data penelitian (Sudaryono, 2018:206). Adapun instrument yang digunakan untuk mengumpulkan data adalah inventori keintegrasian muatan pelajaran di buku guru dan buku siswa kelas 3 tema Perkembangan Teknologi pada masingmasing komponen, yakni 1) materi pelajaran; 2) rancangan langkah-langkah kegiatan pembelajaran; 3) rancangan penilaian, dan; 4) rancangan media dan sumber belajar.

Data dan sumber data yang akan dianalisis dikumpulkan (data collection). Data dan sumber data yang dikumpulkan merupakan data yang berasal dari analisis keintegrasian muatan pelajaran sekolah dasar di buku guru dan siswa kelas 3 tema Perkembangan Teknologi Kurikulum 2013 pada komponen pembelajaran.
Subjek penelitian adalah orang atau siapa saja yang dapat membantu memperoleh data yang diingankan demi kepentingan penelitian (Sugiyono, 2010: 300). Informan utama dalam penelitian yang dijadikan subyek penelitian ini adalah buku guru dan buku siswa kelas III tema Perkembangan Teknologi dalam Kurikulum 2013. Sedangkan objek dalam penelitian ini adalah Kurikulum 2013 yang ditinjau dari buku guru dan buku siswa kelas 3 tema Perkembangan Teknologi.

Pada penelitian ini mengumpulkan data dengan teknik studi dokumen. Dokumen bisa berbentuk tulisan, gambar, atau karya-karya monumental seseorang (Sugiyono, 2014:329). Dokumen yang dimaksud dalam penelitian ini adalah buku guru dan buku pegangan siswa tema Perkembangan Teknologi pada kurikulum 2013. Dokumen adalah catatan tertulis yang isinya merupakan pernyataan tertulis yang disusun oleh seseorang atau lembaga untuk keperluan pengujian suatu peristiwa, dan berguna bagi sumber data (Ibid, 2013: 183). Dokumen yang diambil adalah data di buku guru dan buku siswa yang berkaitan dengan muatan pelajaran kelas 3 tema Perkembangan Teknologi pembelajaran Kurikulum 2013 pada komponen pembelajaran.

Adapun instrument yang digunakan untuk mengumpulkan data adalah inventori keintegrasian muatan pelajaran di buku guru dan buku siswa kelas 3 tema Perkembangan Teknologi pada masingmasing komponen, yakni 1) materi pelajaran; 2) rancangan langkah-langkah kegiatan pembelajaran; 3) rancangan penilaian, dan; 4) rancangan media dan sumber belajar.

Contoh inventori pengumpulan data yang akan digunakan dalam penelitian ini adalah sebagai berikut

Tabel 1. Contoh Inventori Pengumpulan Data

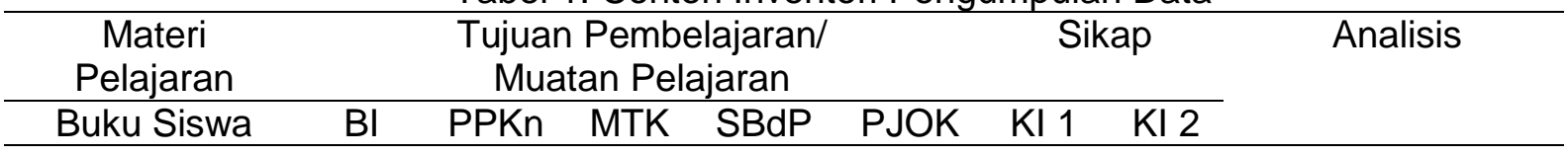

Metode analisis yang digunakan dalam penelitian ini adalah analisis data kualitatif menurut Miles dan Huberman (dalam Sugiyono, 2013: 337-345), 
terdapat empat macam yaitu; (1) pengumpulan data; (2) reduksi data; (3) penyajian data; pengambilan kesimpulan; dan (4) Verifikasi.

Pengumpulan data merupakan tahap pertama yang dilakukan untuk memperoleh data yang dibutuhkan dalam penelitian. Peneliti mengumpulkan sesuai dengan pedoman penelitian yang telah disusun. Data tentang muatan pelajaran sekolah dasar pada buku guru dan siswa kelas 3 tema Perkembangan Teknologi pada Kurikulum 2013 yang diperoleh peneliti melalui dokumentasi dicatat dan dikumpulkan oleh peneliti guna mendukung tahap penelitian selanjutnya sebagai bahan analisis keintegrasian muatan pelajaran di buku guru dan buku siswa kelas 3 tema Perkembangan Teknologi.

Reduksi data dalam penelitian ini terdiri atas beberapa langkah, yaitu (1) menajamkan analisis; (2) menggolongkan atau pengkategorisasian; mengarahkan; (4) membuang yang tidak perlu dan (5) mengorganisasikan data sehingga simpulan-simpulan finalnya dapat ditarik dan diverifikasi. Reduksi data dapat dihitung menggunakan rumus sebagai berikut:

$$
\begin{aligned}
& P=\frac{\sum X_{i}}{\text { Total }} \% \\
& \text { Keterangan: } \\
& \mathrm{P} \quad \text { : Presentasi Keintegrasian } \\
& \mathrm{X}_{\mathrm{i}} \quad \text { : Nilai Komponen }
\end{aligned}
$$

Selanjutnya, presentasi keintegrasian tersebut dibandingkan dengan kriteria seperti terlihat pada Tabel 2 .

Tabel 2. Konvensi Penilaian Acuan

Patokan (PAP) Skala Lima Tentang Keintegrasian Muatan Pelajaran

Presentase Pencapaian Validitas

(\%)

$\begin{array}{cl}90-100 & \text { Sangat Baik } \\ 80-89 & \text { Baik } \\ 65-79 & \text { Sedang } \\ 40-64 & \text { Rendah } \\ 00-39 & \text { Sangat } \\ & \text { Rendah }\end{array}$

(Sumber: Modifikasi Agung, 2016: 146)
Setelah penggolongan data, maka langkah selanjutnya adalah menyajikan data. Pada penelitian kualitatif penyajian data bisa dilakukan dalam bentuk uraian singkat, bagan, hubungan antar kategori, flowchart, dan sejenisnya. Data yang disajikan dalam penelitian ini berbentuk rangkuman secara deskriptif dan sistematis dari hasil yang diperoleh, sehingga tema sentral dapat diketahui dengan mudah, dan setiap rangkuman diberikan penjelasan dengan memperhatikan kesesuaian dengan fokus penelitian.

Langkah yang terakhir adalah verifikasi data untuk menarik kesimpulan. Penarikan kesimpulan secara deskriptif berdasarkan hasil analisis pada tabel inventori keintegrasian muatan pelajaran.Kegiatan pada tahap ini yaitu: (1) menguji kesimpulan yang diambil dengan membandingkan teori yang ditemukan pakar, terutama teori yang relevan; (2) melakukan proses pengecekan ulang mulai dari pelaksanaan wawancara, dan studi dokumen; (3) membuat kesimpulan untuk dilaporkan sebagai hasil dari penelitian yang dilakukan.

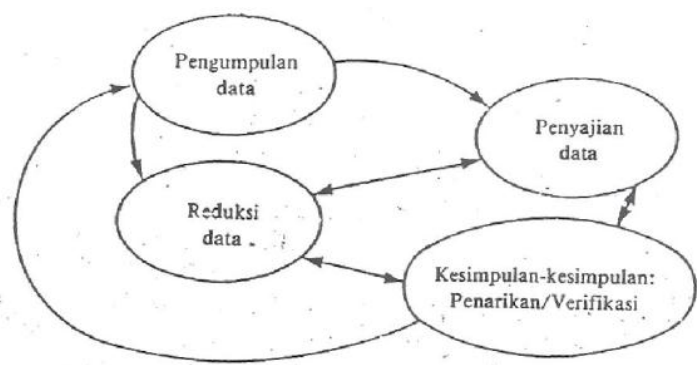

Gambar 1. Komponen-komponen Analisa Data Model Interaktif atau Flow Model (Sugiyono, 2013:337-345) 


\section{HASIL DAN PEMBAHASAN}

Tabel 3. Hasil Analisis Keintegrasian Muatan Pelajaran Pada 4 Komponen Pembelajaran

\begin{tabular}{|c|c|c|c|c|}
\hline \multirow[b]{2}{*}{$\begin{array}{l}\text { Komponen } \\
\text { Pembelajaran }\end{array}$} & \multicolumn{3}{|c|}{ Klasifikasi Keintegrasian } & \multirow[b]{2}{*}{$\begin{array}{l}\text { Persentase } \\
\quad(\%)\end{array}$} \\
\hline & $\begin{array}{l}\text { Tidak Terdapat } \\
\text { Keintegrasian }\end{array}$ & $\begin{array}{c}\text { Integrasi } \\
\text { Intradisipliner }\end{array}$ & $\begin{array}{c}\text { Integrasi } \\
\text { Multidisipliner }\end{array}$ & \\
\hline Materi Pembelajaran (MP) & 1 & 35 & 46 & 98,7 \\
\hline $\begin{array}{ll}\text { Rancangan } & \text { Langkah- } \\
\text { Langkah } & \text { Kegiatan } \\
\text { Pembelajaran } & \text { (RLLKP) } \\
\end{array}$ & 33 & 78 & 49 & 79,3 \\
\hline Rancangan Penilaian (RP) & 24 & 58 & 1 & 71 \\
\hline $\begin{array}{l}\text { Rancangan Media dan } \\
\text { Sumber Belajar (RMSB) }\end{array}$ & 7 & 56 & 15 & 91 \\
\hline TOTAL & 65 & 227 & 111 & 83,8 \\
\hline
\end{tabular}

Pertama, berdasarkan penemuan penelitian Keintegrasian Muatan Pelajaran Pada Materi Pembelajaran Di Kelas 3 Tema Perkembangan Teknologi yang dilihat dari klasifikasi keintegrasian pembelajaran tematik integratif terdapat 2 klasifikasi keintegrasian muatan pelajaran pada materi pembelajaran yaitu integrase intradisipliner dan integrase multidisipliner. Setelah dilakukan analisis terhadap komponen materi pembelajaran (MP) di buku guru dan buku siswa Sekolah Dasar kelas III tema Perkembangan Teknologi. Hasilnya menunjukkan bahwa komponen materi pembelajaran (MP) memiliki tingkat keintegrasian sangat baik sebesar $98.7 \%$ dengan klasifikasi multidisipliner.

Integrasi multidisipliner pada materi pembelajaran sekolah dasar kelas 3 tema Perkembangan Teknologi sebagian besar melibatkan muatan pelajaran Bahasa Indonesia dengan muatan pelajaran lainnya. Kedudukan muatan pelajaran Bahasa Indonesia pada kurikulum 2013 dengan pembelajaran tematik menjadikan Bahasa Indonesia sebagai pintu masuk keintegrasian antar muatan. Hal ini didukung oleh Lailatul Kusniyah (2019) dalam penelitiannya yang mengatakan muatan pelajaran Bahasa Indonesia pada Kurikulum 2013 merupakan penghela ilmu pengetahuan lain pada kelas rendah. Temuan penelitiannya menunjukan bahwa muatan pelajaran Bahasa Indonesia terintegrasi dalam seluruh komponen pembelajaran.

Materi dalam pembelajaran tematik tidak sekedar memberikan pengetahuan saja akan tetapi meliputi aspek pengetahuan, sikap dan keterampilan. Hal ini di dukung oleh pendapat Lukmanul (2011) materi pelajaran atau materi ajar (instructional materials) adalah pengetahuan, sikap dan keterampilan yang harus dipelajari siswa dalam rangka mencapai standar kompetensi yang telah ditentukan. Sikap spiritual (KI-1) dan Sikap sosial (KI-2) terintegrasi secara tidak langsung dalam muatan pelajaran pada materi pembelajaran. Hal ini menunjukan bahwa pembelajaran tematik integrative sudah mengintegrasikan ketiga aspek tujuan pembelajaran yaitu kemampuan siswa dari segi pengetahuan, karakter siswa (sikap), dan keterampilan.

Berdasarkan pemapaan diatas dapat ditarik kesimpulan bahwa materi pelajaran yang terdapat dalam buku teks tematik pada buku siswa maupun buku guru sudah mengaitkan materi dalam sebuah tema atau pembelajaran. Pembelajaran yang saling berhubungan dlam sebuah tema merupakan salah satu model pembelajaran tematik yaitu model connected. Model connected adalah model pembelajaran tematik yang menunjukan keterkaitan dalam satu pembelajaran yang terdiri dari beberapa disiplin ilmu yang berbeda (Trianto, 2011:111).

Kedua, berdasarkan hasil penemuan dari hasil analisis menunjukkan bahwa terdapat 2 klasifikasi keintegrasian pada rancangan langkah-langkah kegiatan pembelajaran di buku guru dan buku siswa sekolah dasar kelas 3 tema Perkembangan Teknologi yaitu integrasi 
multidisipliner dan intradisipliner. Setelah dilakukan analisis terhadap komponen rancangan langkah-langkah kegiatan pembelajaran (RLLKP) di buku guru dan buku siswa Sekolah Dasar kelas 3 tema Perkembangan Teknologi. Hasilnya menunjukkan bahwa komponen rancangan langkah-langkah kegiatan pembelajaran (RLLKP) memiliki tingkat keintegrasian cukup baik sebesar 79,3\% dengan klasifikasi intradisipliner. Integrasi multidisipliner yang terdapat dalam buku guru dan buku siswa pada rancangan langkah-langkah kegiatan pembelajaran adalah terdapat dalam satu muatan pelajaran terdapat lebih dari satu tujuan pembelajaran (TP) yang berbeda muatan pelajaran, misalnya pada rancangan langkah-langkah pembelajaran " Ayo Membaca" memuat muatan Bahasa Indonesia dengan PJOK. Selain itu Integrase multidisipliner yang terdapat pada tema perkembangan teknologi tanpa menggabungkan kompetensi dasar, artinya kompetensi dasar masih terpisah tetapi tetap pada desain pembelajaran yang terintegrasi. Hal ini diperkuat dengan pendapat Forgarty (dalam Prastowo Andi, 2013: 223-224) yaitu Integrasi multidisipliner dilakukan dengan membuat berbagai muatan pelajaran yang diajarkan pada sekolah dasar terkait satu sama lain, sehingga dapat saling memperkuat, menghindari terjadinya tumpang tindih, dan dapat menjaga keselarasan kemajuan setiap muatan pelajaran dan Integrasi multidisipliner dilakukan tanpa menggabungkan kompetensi dasar setiap muatan pelajaran, sehingga setiap muatan pelajaran masih memiliki kompetensi dasarnya sendiri.

Integrase multidisipliner yang terdapat dalam buku guru dan buku siswa hampir secara keseluruhan melibatkan muatan Bahasa Indonesia. Hal ini dikarenakan dalam muatan pelajaran Bahasa Indonesia pada kelas awal yaitu kelas 1 sampai kelas 3 , di muatan Bahasa Indonesia terdapat muatan pelajaran IPA dan IPS. Sedangkan Integrasi Intradisipliner komponen rancangan langkah-langkah kegiatan pembelajaran (RLLKP) yang terdapat pada buku siswa dan buku guru kelas 3 tema perkembangan teknologi adalah terdapat dalam satu muatan pelajaran terdapat lebih dari satu tujuan pembelajaran (TP) muatan yang sama. sedangkan Sikap spiritual (KI-1) dan Sikap sosial (KI-2) terintegrasi secara langsung dalam muatan pelajaran pada rancangan langkah-langkah kegiatan pembelajaran. Hal ini berdasarkan pada tujuan pembelajaran (TP) contohnya pada sub tema 1 pembelajaran 1 "Ayo Bernyanyi" berdasarkan hasil analisis ditemukan RLLKP Ayo Bernyanyi yang memfasilitasi integrasi TP BI 3.6.5 (siswa membaca teks bacaan untuk memahami isi bacaan), TP Bl 3.6.6 (siswa mengidentifikasi ide pokok dari teks) dan TP BI 3.6.7 (siswa menemukan pokokpokok informasi); selanjutnya terintegrasi dengan TP SBdP 3.2.1 (siswa mendengarkan lagu rotiku untuk mengenal pola irama dengan percaya diri). Sehingga disimpulkan terdapat keintegrasian muatan pelajaran $\mathrm{BI}$ dan SBdP pada RLLKP secara multidisipliner.

Berdasarkan pemaparan diatas dapat disimpulkan inetgrasi multidisipliner yang terjadi pada RLLKP selain antar muatan tetapi terdapat dengan bentuk sikap juga. Pendapat tersebut senada dengan pendapat Forgarty (dalam Prastowo Andi, 2013: 223-224) yaitu keterkaitan berbagai muatan pelajaran atau integrase multidisipliner tersebut terbentuk dalam dua hal, yaitu integrasi sikap, pengetahuan dan keterampilan dalam proses pembelajaran serta integrasi berbagai konsep dasar yang berkaitan. Hal ini menunjukan bahwa pembelajaran tematik integrative sudah mengintegrasikan ketiga aspek tujuan pembelajaran yaitu kemampuan siswa dari segi pengetahuan, karakter siswa (sikap percaya diri), dan keterampilan bernyanyi.

Ketiga, keintegrasian pada rancangan penilaian pembelajaran di buku guru dan buku siswa sekolah dasar kelas 3 tema Perkembangan Teknologi yaitu integrasi multidisipliner dan intradisipliner. Setelah dilakukan analisis terhadap rancangan penilaian (RP) di buku guru dan buku siswa Sekolah Dasar kelas 3 tema Perkembangan Teknologii. Hasilnya menunjukkan bahwa rancangan penilaian (RP) memiliki tingkat keintegrasian cukup baik sebesar $71 \%$ dengan klasifikasi 
intradisipliner. Integrasi multidisipliner yang terdapat dalam buku guru dan buku siswa pada rancangan penilaian pembelajaran tema Perkembangan Teknologi adalah terdapat dalam satu alat atau rubric penilaian memfasilitasi lebih dari satu muatan pelajaran yang berbeda berdasarkan TP (tujuan pembelajaran). Hal ini terdapat pada pembelajaran ke-16. Sedangkan integrase intradisipliner pada penilain hanya satu pembelajaran yang tidak terdapat integrase intradisipliner. Disamping itu penilaian pada buku guru sekolah dasar kelas 3 tema Perkembangan Teknologi terdapat 3 aspek penilaian yaitu pengetahuan, sikap, dan keterampilan. Integrasi pada komponen penilaian di buku guru dan buku siswa sekolah dasar kelas 3 tema perkembangan teknologi terlihat dari instrumen dan rubrik penilaian yang digunakan.

Pada penilaian proses yakni penilaian sikap terintegrasi pada aspek sikap yang diamati. Pada penilaian hasil yaitu aspek pengetahuan terlihat dari bentuk tes yang digunakan. Tes yang digunakan untuk ranah kognitif berbentuk tes tertulis dan lisan. Pada aspek keterampilan terlihat dari rubrik penilaian yang digunakan, misalnya keterampilan (a) memperagakan variasi pola irama yang berbeda, (b) intonasi, dan (c) sikap bernyanyi. Penilain pada pembelajaran tematik terpadu (integrasi) berdasarkan pada buku guru kelas 3 tema perkembangan teknologi adalah kegiatan untuk mendapatkan berbagai informasi secara komprehensif (menyeluruh) baik itu dilihat dari proses maupun hasil pembelajaran. Oleh karena demikian senada dengan pernyataan tersebut menurut Mamat S.B. dkk (2005:46) mengatakan bahwasanya , penilaian pembelajaran tematik dilakukan pada dua hal, yaitu penilaian terhadap proses kegiatan pembelajaran dan hasil kegiatan

Keempat, keintegrasian pada rancangan media dan sumber belajar pembelajaran di buku guru dan buku siswa sekolah dasar kelas 3 tema Perkembangan Teknologi yaitu integrasi multidisipliner dan intradisipliner. Setelah dilakukan analisis terhadap rancangan media dan sumber belajar (RMSB) di buku guru dan buku siswa Sekolah Dasar kelas 3 tema Perkembangan Teknologi. Hasilnya menunjukkan bahwa rancangan media dan sumber belajar (RMSB) memiliki tingkat keintegrasian sangat baik sebesar $91 \%$ dengan klasifikasi intradisipliner.Disamping itu terdapat juga penilaian yang tidak terintegrasi. Penggunaan media dan sumber belajar yang terdapat pada buku guru dan siswa kelas 3 tema perkembangan teknologi menyesuaikan dengan tema seperti penggunaan media berbagai gambar alat transportasi dan teknologi pangan. Media tersebut tidak sekedar memfasiltasi muatan pelajaran Bahasa Indonesia tetapi memfasilitasi juga muatan yang lainya. Berdasarkan hasil penemuan dari analisis pengguanaan media dan sumber belajar pada buku tema perkembangan teknologi ditemukan bahwa terdapat 3 ranah yang menjadi tujuan pengetahuan, sikap, dan keterampilan.

Secara kumulatif pada 4 komponen pembalajaran ditemukan 65 yang tidak terdapat keintegrasian, 227 keintegrasian secara intradisipliner dan ditemukan 111 keintegrasian secara multidisipliner. Sehingga dapat disimpulkan kecenderungan keintegrasian muatan pelajaran pada 4 komponen pembelajaran di buku guru dan buku siswa sekolah dasar kelas 3 tema perkembangan teknologi secara keseluruhan yaitu integrasi intradisipliner (227 keintegrasian) dengan tingkat keintegrasian cukup tinggi (baik).

\section{PENUTUP}

Dari paparan diatas dapat
disimpulkan bahwa; (1) terdapat keintegrasian muatan pelajaran pada materi pelajaran (MP) sekolah dasar kelas 3 tema perkembangan teknologi yaitu integrasi multidisipliner (46 keintegrasian) dengan persentase keintegrasian sebesar $98,7 \%$ berkategori sangat baik; (2) terdapat keintegrasian muatan pelajaran pada rancangan langkah-langkah kegiatan pembelajaran (RLLKP) di buku guru dan buku siswa sekolah dasar kelas 3 tema perkembangan teknologi yaitu integrasi intradisipliner (78 keintegrasian) dengan persentase keintegrasian sebesar 79,3\% berkategori cukup baik; (3) terdapat 
keintegrasian muatan pelajaran pada rancangan penilaian (RP) di buku guru dan buku siswa sekolah dasar kelas 3 tema perkembangan teknologi yaitu integrasi intradisipliner (58 keintegrasian) dengan persentase keintegrasian sebesar $71 \%$ berkategori cukup baik; (4) terdapat keintegrasian muatan pelajaran pada rancangan media dan sumber belajar (RMSB) di buku guru dan buku siswa sekolah dasar kelas 3 tema perkembangan teknologi yaitu integrasi intradisipliner (56 keintegrasian) dengan persentase keintegrasian sebesar 91\% berkategori sangat baik; (5)kecenderungan keintegrasian muatan pelajaran pada 4 komponen pembelajaran di buku guru dan buku siswa sekolah dasar kelas 3 tema perkembangan teknologi secara keseluruhan yaitu integrasi intradisipliner (227 keintegrasian)

Adapun beberapa saran yang perlu diperhatikan oleh Peneliti selanjutnya diharapkan untuk mengkaji lebih banyak sumber ataupun referensi yang terkait dengan pembelajaran tematik integrative serta lebih teliti lagi dalam menganalisis konten muatan tematik pada buku guru dan buku siswa. Diharapkan dengan melalui tulisan ini dapat memberikan informasi atau pun pengetahuan yang baru kepada praktisi pendidikan khususnya kepada guru-guru sekolah dasar.

\section{DAFTAR RUJUKAN}

Arikunto, S. 2013. Prosedur Penelitian: Suatu Pendekatan Praktik. Jakarta: PT Asdi Mahasatya.

Dantes, Nyoman. 2017. Pedagogik Dalam Perspektif Nyoman Dantes. Singaraja: Undiksha Press

Ibid. 2013. Manajemen Penelitian. Jakarta: Rineka Cipta

Isjoni. 2007. Integrated Learning. Pendekatan Pembelajaran IPS di Pendidikan Dasar. Bandung: Falah Production.

Julianto. (2010). Kajian Teori Dan Implementasi Model Pembelajaran Terpadu Dalam Pembelajaran Di Kelas. Surabaya: Unesa University Press
Kemendikbud. (2014). Materi Pelatihan Guru Implementasi Kurikulum 2013 Tahun 2014. Jakarta: Kemendikbud.

Kemendikbud.2016. Panduan

Pembelajaran Tematik Terpadu Di

Sekolah Dasar. Kementerian

Pendidikan Dan Kebudayaan

Direktorat Jenderal Pendidikan Dasar

Dan Menengah Direktorat

Pembinaan Sekolah Dasar

Lailatul Kusniyah.2019. Integrasi Muatan Bahasa Indonesia Dalam

PembelajaranTematik Kelas I MI

Roudlotul Tholibin Banjarejo

Rejotangan. Tesis. Program

Pacsarjana.Universitas Negeri

Malang

Lukmanul. 2001. Perencanaan

Pembelajaran. Bandung: Pustaka Setia

Mamat. S.B.dkk. 2005.Pedoman Pelaksanaan Pembelajaran Tematik. Jakarta: Dirjen Kelembagaan Agama Islam. Depag R.I.

Murfiam, Uum. 2017. Model Pembelajaran Terpadu Di Sekolah Dasar. Jurnal Pesona Dasar. Vol. 1 No. 5, April 2017. 25 November 2019

Narti, Y., Setyosari, P., Degeng, I. N. S., \& Dwiyogo, W. D. (2016). Thematic Learning Implementation In Elementary School (Phenomenology Studies In Pamotan Sdn 01 And 01 Majangtengah Dampit Malang). International Journal Of Science And Research.18 November 2019

Peraturan Menteri Pendidikan Dan Kebudayaan Republik Indonesia Nomor 67 Tahun 2013 Tentang Sruktur Kurikulum SD/MI

Prastowo, Andi. 2013. Pengembangan Bahan Ajar Tematik. Jogjakarta: Diva Press

Randel, I. 2010. "The Measure of Success: Integrated Thematic Instruction". The Clearing House, 71, 85-87

$\begin{array}{ccc}\text { Sani, Abdullah } & \text { Ridwan. } & 2014 . \\ \text { Pembelajaran } & \text { Saintifik } & \text { Untuk }\end{array}$


Implementasi Kurikulum 2013. Jakarta: PT. Bumi Aksara

Sugiyono. (2013). Metode Penelitian Pendidikan: Pendekatan Kuantitatif, Kualitatif, $R \& D$. Bandung: AL Fabeta

Sugiyono. 2010. Memahami Penelitian Kuantitatif Kualitatif Dan $R \& D$. Bandung:

Sudaryono.2018. Metodelogi Penelitian. Depok: Raja Grafindo

Tirtarahardja, U.\& Sulo L.S. 2005. Pengantar Pendidikan. Jakarta: Pt Asdi Mahasatya

Trianto. (2010). Model Pembelajaran Terpadu. Jakarta: PT Bumi Aksara.

Trianto. (2014). Model Pembelajaran Terpadu. Jakarta: PT Bumi Aksara. 